\title{
PUBLICATIONS of the
}

\section{AMERICAN SOCIETY OF AGRONOMY and of the \\ SOIL SCIENCE SOCIETY OF AMERICA}

\section{THE JOURNAL OF THE AMERICAN SOCIETY OF AGRONOMY \\ Issued on the 15 th day of each month at Geneva, N.Y., U.S.A.}

Contains original articles on research, teaching, and extension in soils and crops. Approximately 1000 pages a year and includes the proceedings of the annual meeting of the Society. Numerous back numbers also available.

Subscription price, $\$ 5.00$ per volume (12 numbers) in the United States and Canada; \$5.50 elsewhere. Sample copies supplied upon request.

GENERAL INDEXES (AUTHOR AND SUBJECT) TO THE JOURNAL Index of Vols. 1-20, inclusive (1907-1928), 44 pages with covers \$0.50 post paid Index of Vols. 21-30, inclusive (1929-1938), 83 pages with covers $\$ 1.00$ post paid

\section{PROCEEDINGS OF THE SOIL SCIENCE SOCIETY OF AMERICA}

Contains papers given at the annual meetings of the Society; also reports and business transactions.

Volume 1 (1936), 526 pages, illustrated

$\$ 5.00$ post paid

Volume 2 (1937), 602 pages, illustrated $\$ 5.00$ post paid

Volume 3 (1938), 370 pages, illustrated $\$ 5.00$ post paid

PROCEEDINGS OF THE FIRST INTERNATIONAL CONGRESS OF SOIL SCIENCE

Volumes 1 to 4 (Commissions I, II, III and IV, and V and VI, respectively)

$\$ 2.50$ per set of 4 volumes, post paid

BULLETIN OF THE AMERICAN SOIL SURVEY ASSOCIATION (Discontinued)

Nos. XI, XII, XIII, XIV, XV, XVI, and XVII (1930-1936)

$\$ 2.50$ each, post paid

ADDRESS ALL COMMUNICATIONS TO

J. D. LUCKETT, Editor

American Society of Agronomy

GENEVA, N.Y., U.S.A. 


\section{CONTENTS}

PAGS

1. PIPER, C. S. Investigations on copper deficiency in plants. (With Plates 3-7 and one text-figure)

2. Haunan, E. T. Observations on the value of whale-mest meal as a constituent of chick diets, with a note on the influence of added protein on the efficiency of utilization of the gross energy of a ration . . .

3. Sesman, P. A. and SEN, K. C. Studies on carotene in relation to animal nutrition. Part I. The technique of earotene estimation in feeding stuffis

4. Seshan, P. A. and Sen, K. C. Studies on carotene in relation to animal nutrition. Part II. The development and distribution of carotene in the plant and the carotene content of some common feeding stuffs . .

5. Stmphens, S. G. Yield characters of selected oat varieties in relation to cereal breeding teohnique. (With three text-figures) . . . .

6. BriL, G.D.H., Gruson, M. R. and Weston, W. A. R. Druon. Experiments on eutting potato tubers. (With Plate 8)

The Journal of Agricultural Science is issued in quarterly parts of about 150 pages with plates and figures, four parts constituting a volume.

Volumes XVI-XX (1926-1930) sre out of print. Quotations can be given for other back volumes and parts.

Quotations can also be given for buckram binding cases and for binding subseribers' sets.

Papers for publication should be typewritten or written in a very legible hand, and may be sent to Dr F. H. A. Marshal L, School of Agriculture, Cambridge, or to the associate Editors. Other communications should be addressed to the University Press, Cambridge.

\section{form:}

Bibliography should be given under the heading of "References" in the following

Surname of authors (in alphabetical order), initials, date of publication (in brackets), title of Journal (abbreviated according to the World List of Scientific Periodicals), volume and pages of reference. In the text a reference should be quoted by the author's name and date (in brackets).

All names of Journals and books should be in italics.

Contributors will receive twenty-five copies of their papers free. A limited number of additional copies may be purchased if ordered when final proof is returned.

The subscription price for each volume, payable in advance, is $30 s$. net per volume (post free); single numbers 10s. net. Subscriptions may be sent to any Bookseller, or to The Cambridge University Press, Bentley House, 200 Euston Road, London, N.W. 1.

The Cambridge University Press has appointed the University of Chicago Press, agents for the sale of The Journal of Agricultural Science in the United States of America. 